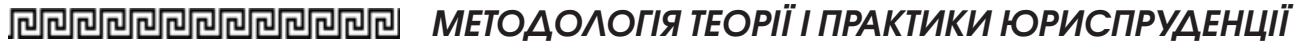

УДК 342.41

DOI https:/ / doi.org/10.32837/yuv.v0i6.2027

\author{
Г. Берченко, \\ кандидат юридичних наук, доцент, \\ доцент кафедри конституційного права України \\ Національного юридичного університету імені Ярослава Мудрого
}

\section{КОНСТИТУЦІЯ ЯК ОСНОВНИЙ ЗАКОН: ПРОБЛЕМИ ТЕОРІЇ І ПРАКТИКИ}

Чи є конституція основним законом, і якщо так, то чому? Відповідь на це питання лежить в історичній площині, проте на нього не можна відповісти також без звернення до сучасної доктрини та державно-правової практики.

Метою статті $€$ з'ясування співвідношення конституції та основного закону. Завданнями статті є встановлення історичної генези основних законів; з'ясування поглядів на співвідношення конституціі та основних законів в науці; з'ясування практики використання терміна «основний закон» як синоніма конституції.

Щодо аналізу останніх досліджень, то варто відзначити, що відповідна проблематика грунтовно розглядається в науці. Про це свідчать дослідження А. Есмена [1], Е. Понтовича [2], В. Шаповала [3], К. Шмітта [4] та інших учених.

Основні закони зовсім не означають законів незмінних, хоча в попередні часи вони розумілися іноді в цьому сенсі. В Середні віки замість одного основного закону існували окремі станові привілеї або вольності, які складалися договірним шляхом і не могли змінюватися інакше, ніж за згодою сторін. Цей порядок випливав із розуміння держави не як єдиного цілого, а як сукупності різних суспільних союзів та осіб з різними правами та обов'язками [5, с. 319].

Як стверджує О. Тарановський, основні закони ("lois fondamentales") держави - це об’єктивні межі, що покладені королівському повновладдю. Вони випливають із життевих потреб самої держави. Ця сторона справи знаходить свій вираз у протиставленні закону державця ("loi du roi") i закону держави ("loi du royaume"). Це протиставлення було сформульоване Паризьким парламентом на "lit de justice" 4 липня 1581 року. Король Генріх III з'явився в парламент, щоби провести актом свого повновладдя фінансові едикти, які парламент відмовився реєструвати. Незважаючи на присутність короля, парламент впирався у своїй відмові, поки не отримав прямого наказу приступити до реєстрації. Беручи до уваги це найвище веління, перший президент (голова) заявив, що «за законом короля, який полягає в його абсолютній владі, едикти могли пройти; але за законом держави, який полягає в розумі і справедливості, вони не могли і не можуть бути оприлюднені». Закон держави є тим верховним поняттям, під яке підводилися всі окремі основні закони. Це основний закон про непорушність зовнішнього суверенітету короля, визнаний парламентом у 1615 році; Салічний закон про престолонаслудівання, що урочисто підтверджений у 1593 році; закон про невідчужуваність королівського домену і деволюції особистого домену короля до корони, що міцно встановлені в судовій та політичній практиці парламенту; принцип неподільності державного правління, визнаний під час установ- 
лення регентства у 1643 році. Безсумнівно, що та вимога самообмеження, яку пред'являла королю парламентська догма, мала характер основного закону, або «істинного стану французької монархіі», як це було сформульовано у 1652 році [6, с. 382-383].

Натомість Е. Понтович не погоджувався 3 О. Тарановським у спробах довести зв'язаність короля основними законами, які не підлягають одноособовій зміні королем. В якому відношенні обмежують королівську владу постанови про незмінність монархічної форми правління, зовнішній суверенітет держави? Ці формули можуть бути віднесені до основних законів в матеріальному аспекті, але жодним чином не можуть бути віднесені до тез про формальні обмеження королівської влади. Низка інших постанов справді має характер обмежень, але їх походження грунтується на феодально-становому ладі. Загалом, на його думку, з ідеєю абсолютної монархії несумісні ідея закону, що має особливу формальну силу, ідея конституції, оскільки у незв'язаності короля законами полягає сутність абсолютизму [2, с. 24-26].

Варто погодитися 3 Б. Чичеріним у тому, що сама відмінність між основними законами і звичайними існує не скрізь. Практичне значення це має лише там, де правом видавати й змінювати основні закони і звичайні наділені різни влади, тобто там, де влада установча відокремлена від законодавчої. В Англії, де обидвома владами наділений король у парламенті, цього розмежування не існує [5, с. 318]. Це дуже важлива теза, адже виходить, що може існувати конституція в матеріальному значенні (поза розумінням основного закону саме як акта найвищої юридичної сили). Наголосимо на тому, що йдеться про відсутність у британському праві основних законів в розумінні формальної відмінності та вищої юридичної сили порівняно зі звичайними законами. За матеріальним кри- терієм їх можна виділити. Фактично йдеться виключно про характер предмета регулювання (матеріальний критерій), а не про критерій вищої юридичної сили.

Отже, саме приклад США і Франціï показує значення основних законів у формальному сенсі за критерієм юридичної сили. До XVIII ст., коли відбулися американська й французька революція, державне право різних європейських країн, спиралось майже виключно на звичай. Лише іноді зустрічалися деякі писані конституційні тексти, частіше за все урочисті заяви, щодо яких монарх давав свою згоду, яким він обіцяв слідувати сам, а також від імені своїх нащадків, а іноді трактати й капітуляції, укладені незалежними державами в момент, коли вони погодилися об'єднатися в єдину державу. Англія, що залишилася поза революційним рухом XVIII ст., зберігала конституцію саме такого роду. Більшою частиною англійське державне право засноване на звичаї; воно містить лише невелику кількість писаних законів; найважливішими 3 яких є Велика Хартія та іiі пізніші підтвердження, петиція прав, Білль про права, Акт про престолонаслідування 1700 року і трактати про приєднання Шотландіi та Ірландіï. Публіцисти XVIII ст. уявляли собі конституцію не інакше, як у вигляді основного й систематичного писаного закону. Таке уявлення будувалося на трьох міркуваннях. По-перше, тоді всіма визнавалася перевага писаного закону над звичаєм; у формі закону слід було виразити конституційні норми. По-друге, люди XVIII ст. охоче дивилися на нову конституцію, проголошену суверенним народом, як на відновлення суспільного договору, отже, необхідно було виразити умови цього договору в найбільш урочистій і повній формі. Нарешті, вони думали, що редаговані таким чином конституціï, зрозумілі та систематичні, могли слугувати чудовим знаряддям політичного виховання, оскільки вони, 


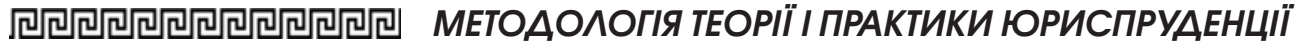

безперечно, поширять серед громадян знання їх прав і водночас прив'яжуть iх до цих прав [1, с. 386].

Досить активно вживається поняття «основний закон» у Північній Європі. Основним законом прямо в тексті названа форма правління Швеціï 1809 року. Як стверджує М. Ісаєв, термінологічно поняття «конституція» в цих країнах відсутне. Замість нього вживають термін «основний закон» ("Grundlov"), який протиставляється континентальній і англо-американській традиції, що виражається терміном "constitution". Більш змістовним вважається термін “forfatning' (дат./ норв.), “forfattning” (швед.), аналогічний німецькому "Verfassung", який вживається для позначення всіх норм, що регулюють вищу державну владу ("statsstyre"), незалежно від того, закріплені вони в одному або декількох правових актах чи не закріплені в письмовій формі взагалі. Звідси випливає, що, навіть маючи формальний акт, що має назву «Основний закон» (Данія, Норвегія) або «Форма правління» (Швеція), конституція в цих країнах в матеріальному сенсі є сукупністю актів, що складаються з норм одного порядку, що переважно визначає, хто може здійснювати державно значимі діі. Сюди ж входять норми, що регулюють права й свободи громадян, оскільки вони говорять фактично про те, що не повинні діяти органи держави. Регулювання відбувається по лінії визначення компетенції, проте вже в негативному сенсі. Таким чином, виникає проблема щодо того, чи містить конституція норми формального або матеріального права [7, c. 149].

Як зазначав С. Котляревський, Основні Закони Російської Імперії 1906 року належать до класу писаних конституцій. В цьому закони 23 квітня 1906 року не є чимось оригінальним, і та обставина, що вони не називаються конституційними, жодним чином не змінює сутності справи. Мотиви, за якими автори Основних
Законів не вважали можливим вживати термін «конституція» або «конституційний», тут не мають значення. 23 квітня 1906 року Росія отримала конституційну хартію [8, с. 6].

Офіційне застосування терміна «основний закон» характеризувало радянську практику та практику країн так званої народної демократії, а згодом соціалістичного табору. В Українській РСР у 1937 і 1978 роках вживали подвійний титул: Конституція (Основний Закон). Однак найбільш суттєвим є те, що визначення радянських конституцій як основних законів було одним 3 проявів концепції верховенства рад [3, с. 26].

Сьогодні окремі українські вчені (передусім С. Головатий) вживають з етимологічних причин термін «основоположний закон». Проте офіційно (в преамбулі Конституції України) ми маємо згадку про Конституцію України саме як про «Основний Закон» (відповідне словосполучення наведене в дужках), тому маємо поважати чинне формулювання, хоча в перспективі, звісно, можна ставити питання про уточнення відповідного терміна під час прийняття нової Конституції України або внесення змін до чинної.

Досить велику традицію вживання терміна «основний закон» мають німецькомовні країни. Основні Закони Австро-Угорщини, вони ж конституційні закони, складалися з трьох частин, таких як закони уніі, закони Австріі і закони Угорщини. Закони унії включали, окрім різних правил, що стосувалися престолонаслідування, Прагматичну санкцію 1713 року і закони, спільні для Австрії та Угорщини, датовані груднем 1867 року, що встановлювали взаємні відносини двох держав і способи управління спільними справами. Основні закони Австрії складалися 3 різних королівських декретів, дипломів та указів, що стосувалися складу, привілеїв тощо Національного Рейхсрату і провінційних ландтагів. Конституційне право Угорщини 
базувалось на Золотій Буллі Андрія II, даної у 1222 році, що стосувалася станових привілеїв; згодом на деяких законах 1790-1791 років, що стосувалися політичної незалежності Угорщини та функціонування законодавчої і виконавчої влади; на законах 1847-1848 років, що встановлювали відповідальність міністрів, і на одному законі 1868 року [9, с. 302-303]. Вочевидь, саме через відповідні історичні передумови і традиції сучасна Конституція Угорщини 2011 року також має назву «Основний Закон».

Досить повно описував значення терміна «основний закон» ("Basic Law,"Basic Norm or Lex Fundamentalis", в оригіналі німецькою мовою - "Grundgesetz") у 1928 році Карл Шмітт. Вчений зазначав, що цей термін може мати такі значення.

1) У загальному, а не в точному сенсі усі статути чи угоди, які, як видається, мають особливе політичне значення для осіб чи груп, що мали політичний вплив на той час, називаються основними законами. Отже, численні угоди, поступки, привілеї німецьких маєтків щодо німецького кайзера називалися основними законами ("leges fundamentales").

2) Основний закон = абсолютно непорушна норма, яка не може бути жодним чином змінена або порушена іншими нормами.

3) Основний закон = кожна відносно непорушна норма, яка може бути змінена або порушена іншими нормами лише за кваліфікованих передумов.

4) Основний закон = останній уніфікований принцип політичної єдності та всього порядку. У цьому разі цей термін є вираженням абсолютної концепції конституціі.

5) Основний закон = кожен окремий принцип державної організації (основні права, поділ влади, монархічний принцип, так званий представницький принцип тощо).

6) Основний закон = остання норма для системи нормативних при- писів. Тут виділяється нормативний характер, перш за все підкреслюється закон в основному законі.

7) Основний закон = будь-який організаційний регламент юрисдикції та процедури політично найважливішої діяльності держави. У федерації це включає навіть установлення прав федерації окремо від прав їі членів.

8) Основний закон = будь-яке обмеження державної влади чи діяльності через нормативні рамки.

9) Основний закон = конституція в позитивному сенсі, згідно з яким так званий основний закон не зводиться до статутних норм, навпаки, його сутнісним змістом є політичне рішення [4, с. 94].

До речі, сьогодні у Федеративній Республіці Німеччина конституція названа саме «Основний Закон». Відповідна мотивація щодо назви була обумовлена, за задумом авторів, тимчасовим характером діï ухваленого після Другої світової війни у 1949 році акта (який зберіг свою чинність досі).

Використання словосполучення «основний закон» піднімає також часто питання про те, основним законом держави чи суспільства $€$ конституція. Питання щодо того, чи $€$ конституція основним законом держави чи суспільства, піднімалося в радянській літературі. Н. Міхальова зазначала, що характеристика соціалістичної конституції як конституції держави правильніше відображає іiі зміст. За своєю юридичною природою соціалістична конституція є державно-правовим актом, основним законом саме держави. Конституція як правовий акт вищої юридичної сили видається в результаті правотворчої діяльності держави [13, с. 42].

Насправді визнання конституції основним законом держави притаманно було не лише радянській доктрині. Як стверджували А. Демишель, Ф. Демишель, М. Пикемаль, конституція - основний закон держави - має вищу юридичну силу по відношенню до всіх інших державних 


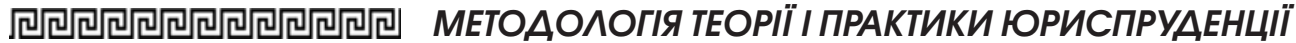

актів [14, с. 22]. Як зазначає $\mathrm{K}$. Хессе, як основний правопорядок життя суспільства конституція не обмежується встановленням державного ладу. Вона охоплює - особливо яскраво це проявляється під час забезпечення інститутів шлюбу і сім’і, власності, освіти й дії соціальних груп або свободи в мистецтві і науці також основи устрою недержавного життя, тому конституційне право більш об'ємне, ніж право державне, яке за значенням і змістом означає лише право держави. 3 іншого боку, конституційне право обмежене порівняно 3 державним в тому аспекті, що державне право включає, наприклад, адміністративне й процесуальне права, які не належать до основоположного статуту суспільного устрою [10, с. 28-29].

На думку В. Шаповала, не викликає сумнівів, що будь-яка конституція відіграє вагому соціально-регулятивну роль, саме в цьому сенсі вона має сприйматися як основний закон суспільства. Проте навіть найбільш соціалізовані конституціі $€$ передусім основними законами держави. $\mathrm{Ti}$ їні приписи, котрі адресовані суспільству, сформульовані у загальній формі, вони виглядають фрагментарними й зазвичай відображають взаємодію суспільства та держави $[15$, с. 117]. Визначення конституціï основним законом держави не означає підміну соціуму державою, одержавлення суспільного буття. Навпаки, воно засвідчує природу громадянського суспільства як такого, де саме суспільство й кожний індивід убезпечені від всебічного втручання держави, а остання $€$ складовою частиною політичної системи суспільства й не поглинає усіх його сутнісних виявів. Конституція як основний закон держави не утворює саму державу, а лише, відповідно до різного за формою волевиявлення народу як носія установчої влади, встановлює засади іï організації, У зв'язку з цим вона відіграє креативну роль стосовно державного механізму, насамперед його найважливіших ланок - вищих органів держави. Політичним завданням конституції як основного закону держави є утвердження суверенітету держави закріпити встановлення або зміну державного ладу, констатувати міру наступництва у розвитку держави. Визначення конституції як основного закону держави підтверджує те, що вона регулює найбільш суттєві політичні відносини державного володарювання, які засвідчують своєрідну архітектоніку держави. Така оцінка відповідних відносин зумовлена роллю вищих органів держави у здійсненні володарювання, особливостями їх конституційної правосуб'єктності, а також повноваженням цих органів вчиняти реальні політичні дії [15, с. 118].

Варто нагадати, що обидва терміни у словосполученні «основний закон» пишуться в преамбулі Конституції України з великої літери. При цьому висловлюється досить критичний підхід до розуміння Конституції України як основного закону держави, а не громадянського суспільства. В. Речицький стверджує, що «ii регулятивний потенціал мав обмежені часово-просторові рамки. Розрахована на реалізацію в посттоталітарній країні, Конституція виявилася помітно недосконалою в умовах розширення політичної свободи й ринку» [16, с. 88].

На думку О. Скрипнюка, Конституція України - Основний Закон суспільства і держави [15, с. 160]. Так само Ю. Тодика стверджував, що конституція є не лише основним законом держави, але й основним законом суспільства, оскільки конституція $€$ продуктом політичної і юридичної згоди, результатом компромісу різноманітних сил у суспільстві $[17$, с. 15].

Існує думка про метафоричність терміна «основний закон». Як зазначає Й. Ізензее, функція конституції, що закладає підвалини єдності й стабільності, отримує своє вираження 
в іï метафоричному визначенні як основного закону. Це означає, що конституція не ідентифікується з усім правопорядком, не регулює все державне й суспільне життя. Конституція планомірно створює відкритий правовий простір для політичних структур, творчої законодавчої політики, а також для відповідального урядового курсу. Основний характер конституції проявляється там, де вона встановлює лише зовнішні кордони політичної дії, однак всередині цих кордонів є вільний політичний простір. Проте державні органи постійно пов'язані конституційно-правовими нормами [18, с. 309].

Конституція може мати характер сукупності основних законів, які ухвалює парламент (конституція Ізраїлю). Сьогодні Конституція Ізраїлю - це 13 основних законів. «3 1958 року по 2015 рік Кнесет прийняв 13 Основних законів, які в майбутньому покликані стати главами Конституції Держави Ізраїль. Кожен Основний закон мислиться як окрема глава майбутньої конституції. Звідси випливає назва цих законів, що відповідає назві глав можливої майбутньої конституції, наприклад «Основний закон: Кнесет», а не «Основний закон про Кнесет». Основні закони відрізняються від звичайних законів за статусом, змістом і формою» [19].

Сьогоднішня Конституція Угорщини 2011 року має назву «Основний Закон». Іспаномовні держави також мають свій аналог «основного закону», що вживається як синонім конституціï, а саме "Carta Fundamental". Це визначення використав Верховний суд Венесуели у рішенні CSJ-SPA (17) від 19 січня 1999 року. "Carta Fundamental” часто називають також конституцію Чилі 1925 року.

Отже, можна дійти таких висновків. Вчення про конституцію формувалося поступово, еволюційно. Конституцію почали сприймати як державний устрій або форму правління, не одразу ототожнюючи іï з окремим писаним формальним джерелом з відповідною назвою. Паралельно розвивалося вчення про основні закони, під якими розумілися саме норми й правила, хоча їх форма могла бути різною. Термін «конституція» поступово витіснив термін «основний закон», хоча у деяких країнах досі залишився у вжитку з різних історичних причин як синонім конституціі.

У статті з'ясовано сутність конституції як основного закону. $B$ rimepamypi nостійно точаться дискусії щцодо того, коли саме у світі з'явилися перші конститущії. Так само постає питання про те, хто віо самого початку звернувся до поняття конституизї в доктринальному розумінні, описуючи відповідне вже наявне поняття або пропонуючи запровадити конституцію як певну ідеальну модель на практиці. Паралельно не вщухають спори щьоо співвідношення конституції та основного закону, сучасного змісту конституйї як державно-правового явища.

Робиться висновок про те, щзо вчення про конституцію формувалося поступово, еволюиійно. Конституцію почали сприймати як державний устрій або форму правління, не одразу ототожнюючи ї з окремим писаним формальним джерелом з відповідною назвою. Паралельно розвивалося вчення про основні закони, під якими розумілися саме норми й правила, хоча їх форма могла бути різною. Робиться висновок про те, що до появи конституцій у формальному значенні особливо важливо підкреслити ї генезу: вона виросла з матеріального значення, будучи доповненою на певному історичному етапі значенням формальним. Термін «конституиія» поступово витіснив термін «основний закон», хоча у деяких країнах досі залишився у вжитку з різних історичних причин як синонім конституції. Досить велику 


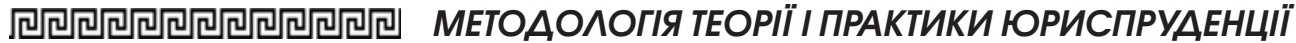

традицію вживання терміна «основнии закон» мають німецькомовні країни. Сьогодні у Федеративній Pеспубліці Німеччина конституція названа саме "Основнии Закон». Відповідна мотивація щодо назви була обумовлена, за задумом авторів, тимчасовим характером дії ухваленого після Другої світової війни у 1949 роцуі акта (який зберіг свою чинність досі). Сьогоднішня Конститущія Угорщини 2011 року має також назву «Основний Закон». Іспаномовні держави також мають свій аналог "основного закону», що вживається як синонім конституuiï, a came "Carta Fundamental".

Ключові слова: конституція, основний закон, ФРН, Угорщина, Україна.

Berchenko H. Constitution as a fundamental law: problems of theory and practice

The article clarifies the relationship between the constitution and the basic law. There is a constant debate in the literature about when the first constitutions appeared in the world. The question also arises as to who from the very beginning turned to the concept of constitution in the doctrinal sense, describing the corresponding already existing concept or proposing to introduce the constitution as a certain ideal model in practice. At the same time, disputes over the relationship between the constitution and the basic law, the modern content of the constitution as a state and legal phenomenon do not subside.

It is concluded that the doctrine of the constitution was formed gradually, evolutionarily. The Constitution began to be perceived as a state system or a form of government, not immediately identifying it with a separate written formal source with the appropriate name. In parallel, the doctrine of the basic laws developed, which meant precisely the rules and regulations, although their form could be different. It is concluded that before the emergence of constitutions in the formal sense, it is especially important to emphasize its genesis - it grew out of material significance, being supplemented at a certain historical stage by the formal meaning. The term "constitution" has gradually supplanted the term "fundamental law", although in some countries it has remained in use for various historical reasons as a synonym for the constitution. German-speaking countries have a long tradition of using the term "fundamental law". Today in the Federal Republic of Germany, the constitution is called the "Fundamental Law". The corresponding motivation for the name was due, according to the authors, to the temporary nature of the act adopted after the Second World War in 1949 (which has remained in force to this day). The current Constitution of Hungary in 2011 is also called the "Fundamental Law". Spanishspeaking states also have their own analogue of the "fundamental law", which is used as a synonym for the constitution - "Carta Fundamental".

Key words: constitution, fundamental law, Germany, Hungary, Ukraine.

\section{Література}

1. Эсмен А. Основные начала государственного права. Т. 2. Москва: Типолиmогр. B. Рихтер, 1899. VII, 399 c.

2. Понтович Э.Э. Развитие конституциии и учредительная власть. Петроград : Огни, 1918. 91 с.

3. Шаповал В. Сучасний конституціоналізм. Київ : Юрінком Iнтер, 2005. 560 c.

4. Schmitt C. Constitutional theory. Durham: Duke University Press, 2008. 468 p.

5. Чичерин Б. Общее государственное право. Москва: Зериало, 2006. 536 с.

6. Тарановский Ф. Догматика положительного государственного права во Франиии при старом порядке. Юрьев : Tun. K. Матmисена, 1911. VII, 633 c.

7. Исаев М. Механизм государственной власти в странах Скандинавии. Москва: Городеи, 2004. 400 c. 
8. Котляревский С. Юридические предпосылки русских основных законов. Москва : Tuп. Г. Лисснера и Д. Собко, 1912. 217 с.

9. Вильсон В. Государство: прошлое и настоящее конституционных учреждений. Москва : Типолитогр. Т-ва печатного и издательского дела в Москве, 1905. 569, XVI c.

10. Хессе К. Основы конституиионного права ФРГ. Москва : Юридическая литература, $1981.368 \mathrm{c}$.

11. Мауни Т. Государственное право Германии (ФРГ и ГДР). Москва : Издательство иностранной литературы, 1959. $596 \mathrm{c}$.

12. Kommers P., Miller A. The Constitutional Jurisprudence of the Federal Republic of Germany. Durham and London: Duke University press, 2012. 904 p.

13. Михалева Н. Социалистическая конституици (проблемы теории). Москва: Юридическая литература, 1981. 152 с.
14. Демишель А., Демишель Ф., Пикемаль М. Институты и власть во Франции . Институционные формы государственно-монополистического капитализма. Москва: Прогресс, 1977. 232 с.

15. Джерела конституиійного права України / відп. ред. Ю. Шемшученко, О. Ющик. Київ : Наукова думка, 2010.711 c.

16. Конституиійне право України : підручник / за заг. ред. Т. Слінько. Харків: Право, 2020. 592 с.

17. Тодька Ю. Конституция Украины - Основной Закон государства и общества. Харьков : Факт, 2001. 382 с.

18. Государственное право Германии. Москва : Российская Академия наук института государства и права. T. 2. 1994. $320 \mathrm{c}$.

19. Основнале законы Государства Израиль. URL https://m.knesset.gov.il/ $\mathrm{ru} /$ activity / pages / basiclaws.aspx. 